\title{
Yes, breast cancer related lymphoedema can be managed
}

\author{
Author: \\ Johanna E. Maree \\ Affiliation: \\ ${ }^{1}$ Adelaide Tambo School of \\ Nursing Science, Tshwane \\ University of Technology, \\ South Africa \\ Correspondence to: \\ Johanna Maree \\ Email: \\ lize.maree@wits.ac.za \\ Postal address: \\ Private Bag X680, Pretoria \\ 0001, South Africa \\ Dates: \\ Received: 26 Aug. 2010 \\ Accepted: 08 July 2011 \\ Published: 17 Oct. 2011 \\ How to cite this article: \\ Maree, J.E., 2011, 'Yes, breast \\ cancer related lymphoedema \\ can be managed', Health SA \\ Gesondheid 16(1), Art. \#578, \\ 7 pages. doi:10.4102/hsag. \\ v16i1.578
}

C 2011. The Authors Licensee: AOSIS OpenJournals. This work is licensed under the Creative Commons Attribution License.
The purpose of the study was to demonstrate that breast cancer related lymphoedema can be managed by means of Complete Decompression Therapy and consequently improve quality of life. An instrumental case study design was used. The target population was all women with breast cancer related lymphoedema living in Tshwane, the context of the study. The patient with the most severe breast cancer related lymphoedema treated by the researcher is presented. Mixed methods were used to gather data. The expected $60 \%$ limb volume reduction could not be achieved after 4 weeks of induction therapy. After 8.5 weeks of treatment, the limb volume reduced from the initial $3841 \mathrm{~mL}$ to $1639 \mathrm{~mL}$, a $57.2 \%$ reduction. Patient compliance to compression therapy was a challenge and led to relapse extending the induction phase of treatment. Despite the prolonged treatment, the limb volume reduction improved the patient's quality of life. The study demonstrated and confirmed that despite a degree of noncompliance, breast cancer related lymphoedema can be managed with Complete Decongestive Therapy which, in turn, improves the quality of life of women living with breast cancer.

Die doelstelling van die studie was om te demonstreer dat borskanker-verwante limfedeem deur middel van Volledige Dekompressie Terapie beheer kan word wat gevolglik die pasiënt se lewenskwaliteit verbeter. 'n Instrumentele gevallestudie-ontwerp is gevolg. Die populasie waaruit die geval gekies is, het uit alle vroue met borskanker-verwante limfedeem in Tshwane, die konteks van die studie, bestaan. Die pasiënt met die ergste limfedeem wat die navorser behandel het, word voorgedra. Gekombineerde metode is ingespan om data in te samel. Die verwagte $60 \%$ vermindering in die armedeem binne 4 weke van induksie behandeling is nie bereik nie. Na 8.5 weke van behandeling het die edeem van die oorspronklike $3841 \mathrm{~mL}$ tot 1639 $\mathrm{mL}$ verminder wat 'n $57.2 \%$ reduksie verteenwoordig. Die pasiënt het nie die voorskrifte ten opsigte van dekompressie terapie noukeurig nagekom nie, wat terugvalling en 'n verlengde induksie-fase tot gevolg gehad het. Die vermindering van die armedeem het die pasiënt se lewenskwaliteit nogtans positief beïnvloed. Die studie het aangetoon dat, ten spyte van pasiënt afvalligheid, dit moontlik was om borskanker-verwante limfedeem deur middel van Volledige Dekompressie Terapie te verminder en lewenskwaliteit te verbeter.

\section{Introduction}

\section{Setting}

\section{Background}

Lymphoedema is a chronic inflammatory lymphostatic disease that is caused by the body's inability to drain lymph fluid from the tissues, which results in the swelling of a body part, most commonly the extremities. Lymphoedema occurs when the lymphatic load exceeds the transport capacity of the lymphatic system, resulting in an abnormal accumulation of protein-rich fluid in the interstitium (Norton School of Lymphatic Therapy 2004; Zuther 2005; Lawenda, Mondry \& Johnstone 2009). Primary lymphoedema is the result of developmental dysplasia of the lymph vessels or lymph nodes (Földi \& Földi 2006) and may be present at birth, or develop later with no obvious cause (Norton School of Lymphatic Therapy 2008). Secondary lymphoedema is more common than primary lymphoedema and is caused by known factors such as surgery, radiation, infection, malignant tumours, immobility and chronic venous insufficiency (Zuther 2005).

It is unknown how many people in Africa live with lymphoedema. The unavailability of statistics is merely part of a worldwide phenomenon as, according to Zuther (2005), no specific studies have been conducted on the incidence of lymphoedema. In 1984, the World Health Organisation (Norton School of Lymphatic Therapy 2008) estimated that 113 million people suffered from lymphoedema, with 90 million caused by parasites, 20 million caused by breast cancer and with 2-3 million people with primary lymphoedema. Földi and Földi (2006) are, however, of the opinion that 140-250 million people worldwide suffer from lymphoedema and that breast cancer 
treatment is one of the most common causes of secondary lymphoedema.

The lack of epidemiological data are also related to the fact that lymphoedema is not a reportable condition (Földi \& Földi 2006). Secondary lymphoedema is, furthermore, commonly viewed as being less important than the eradication and detection of recurrent breast cancer (Petreck \& Heelan 1998). In 1998, Petreck and Heelan (1998) undertook a review of the medical literature and found that the incidence of breast cancer related lymphoedema ranged between $6 \%$ and $30 \%$; however, Clark, Sitzia and Harlow (2005) state that the incidence of breast cancer related lymphoedema ranges between $6 \%$ and $83 \%$.

Lymphoedema is incurable because of permanent damage to, or absence of, the various lymphatic components (Lawenda et al. 2009). People do not die of lymphoedema, but their quality of life is severely impaired. Surgical procedures such as debulking operations, amputations and other unsuccessful or outdated surgical procedures can have disastrous effects on the patient (Földi \& Földi 2006). Complete Decongestive Therapy is the gold standard treatment for lymphoedema (Lawenda et al. 2009) with the main goal of returning the lymphoedema to a stage of latency by using the remaining lymph vessels and other lymphatic pathways. Additional goals of Complete Decongestive Therapy, which have shown an average lymphoedema reduction of the upper extremity of 59.1\% (Lawenda et al. 2009), are the reduction and removal of fibrotic tissue and the prevention and elimination of infections (Zuther 2005).

Complete Decongestive Therapy is a specialised conservative treatment comprising two phases: an induction phase and a lifelong maintenance phase (Norton School of Lymphatic Therapy 2008; Zuther 2005; Földi \& Földi 2006; Lawenda et al. 2009). During the induction phase, the patient is seen and treated on a daily basis. Induction treatment consists of manual lymph drainage of 30-60 minutes at least once a day, 5 days per week and the application of compression bandages. Short stretch bandages are preferred because of their high working and low resting pressure qualities. Before the bandages are applied, the affected limb is moisturised with a moisturiser specifically formulated for a sensitive skin and patients are instructed not to remove the bandages at home. During the induction phase the patient, or a family member, is taught self-bandaging as the patient's lymphoedematous limb needs to be bandaged during weekends and nights for the maintenance phase. The patient receives instructions on decongestive exercises and has to perform these for 10-15 minutes twice a day whilst wearing the bandages (Zuther 2005). Skin and nail care forms part of patient education as well as the signs, symptoms and management of skin infection. The duration of the induction phase varies with the severity of the lymphoedema, or by the patient's response to therapy (Lawenda et al. 2009), and ends when a plateau, indicated by the results of the circumferential or volumetric measurements on the affected extremity, is reached. During the maintenance phase, the patient assumes responsibility for the management of the lymphoedema by maintaining and improving the results of the previous phase. The maintenance phase comprises skin and nail care, self-manual lymph drainage and decompression exercises. During the day, compression garments are worn whilst the patient continues to apply compression bandages at night. Followups are conducted on patients and additional treatment sessions are carried out should the patient be unable to maintain decongestion, or experiences swelling (Zuther 2005).

\section{Problem Statement}

The researcher is of the opinion that health professionals in South Africa commonly regard cancer related lymphoedema as a 'normal' complication of cancer and the treatment of cancer. Should a woman develop lymphoedema, she simply has to accept and live with this complication, as there is no permanent solution available. It is true that there is no cure for lymphoedema, but unfortunately it tends to progress without adequate treatment, which leads not only to body image disturbances and the accompanying decrease in quality of life, but also to health related complications such as inflammatory conditions and even malignant tumours (Földi \& Földi 2006).

\section{Purpose of the study}

The purpose of the study was to demonstrate that breast cancer related lymphoedema is manageable by means of Complete Decompression Therapy, thereby improving the quality of life of the patient.

\section{Research significance}

It is not clear how many people worldwide live with lymphoedema, but it is estimated that the number can be as high 250 million. Breast cancer is considered to be the most common cause of secondary lymphoedema. Breast cancer related lymphoedema is not new to oncology nursing; however, oncology nursing research is extremely sparse. Only one South African study that addresses this problem could be found. In South Africa, we have no evidence of the incidence, the self-management attempts, lived experience or suffering of women living with breast cancer related lymphoedema or the management thereof. This study attempted to provide evidence that lymphoedema caused by cancer and its treatment can be managed to improve the patient's quality of life.

\section{Literature review}

As this study involved nursing practice, Dorothea Orem's Self-care Deficit Nursing Theory was selected as the theoretical framework (Berbiglia 2010). Self-care refers to the activities individuals initiate and perform on their own behalf to maintain life, health and well-being. The ability to engage in self-care is influenced by various factors such as age, health state, health care system factors and the availability and adequacy of resources. A self-care deficit arises when the individual's self-care demands exceed his acquired ability or 
power to engage in self-care. An adult requires nursing in the absence of the ability to maintain the amount and quality of self-care needed to sustain life and health continuously, to recover from disease or injury, or to cope with their effects. Orem (1995) identified three nursing systems in patient care. The first system, the wholly compensatory system, is applicable to the person who is socially dependent on others for the continuation of their existence (Foster \& Bennett 2002); here nurse action is intense and patient action limited. The second system is the partially compensatory system, where the patient has a limited ability to meet his self-care needs and the nurse and patient share the actions of self-care. The third system, the supportive-educative system, is applicable in situations where the patient is able to accomplish selfcare but needs support in terms of learning new self-care activities; here the patient action is intense whilst the nurse action is limited to support (Edmond 2003). Both the partially compensatory and the supportive-educative system were applied in the care of the patient. The patient had limited ability to apply the self-care needed to manage her lymphoedema and had to be assisted by the researcher, a registered nurse. The supportive-educative system was used to teach and support the patient in applying self-care during the induction therapy and to prepare her for the self-care needed throughout the lifelong maintenance phase.

Orem (1995) urges nurses to ask and answer the questions, 'What is?' and 'What can be?', as a departure point in nursing practice situations. Nursing practice, guided by the Self-care Deficit Nursing Theory, is characterised by a caring approach where the nurse uses experiential and specialised scientific knowledge to design and produce the art of nursing care (Berbiglia 2010). Experiential and specialised knowledge of oncology nursing and Complete Decongestive Therapy were applied to assess the patient in answering the question 'What is?', as well as to design and implement a care plan to answer 'What can be?'

\section{Definition of concepts}

Quality of life: Quality of life is an ill-defined term and means different things to different people (Fayers \& Machin 2007). In 1993 the World Health Organisation Quality of Life Group (Bowling 1996) defined quality of life as 'an individual's perception of their position in life in the context of the culture and value systems in which they live and in relation to their goals, expectations, standards and concerns. It is a broad ranging concept affected in a complex way by the person's physical health, psychological state, level of independence, social relationships and their relationships to salient features of their environment.'

Complete Decongestive Therapy: Complete Decongestive Therapy is specialised, conservative, long-term therapy consisting of skin and nail care, manual lymph drainage, application of bandages, decongestive exercise and medical compression garments (Weissleder \& Schuchhardt 2008).

\section{Research design and methods Research design}

The design used was a mixed method, descriptive instrumental single case study. An instrumental case study design is used when insight into an issue is pursued or when a generalisation is challenged (Barroso 2010) and allows researchers to focus on their concerns as highlighted by the case (Luck, Jackson \& Usher 2006). The research design was applicable to the study as the researcher wished to present the uniqueness of the participant's situation and challenged her own concerns, namely the perception of health professionals that 'nothing can be done for women living with breast cancer related lymphoedema'.

\section{Context of the study}

The context for the study was Tshwane, a municipal area in South Africa's smallest province, Gauteng Province. The total population of Gauteng is 8.8 million, which represents approximately $20 \%$ of the total South African population. More than $60 \%$ of the research and development of South Africa takes place in Gauteng, which also has the hightest per capita income in South Africa. Tshwane hosts a population of approximately 2 million (SouthAfrica.info 2010), but it is unknown how many women in Tshwane have breast cancer or breast cancer related lymphoedema, as no statistics are available.

\section{Population and sample}

The target population was all women living with breast cancer related lymphoedema in Tshwane. The accessible population, from which the sample was obtained (Burns \& Grove 2005), was all women who had entered a specific lymphoedema project in Tshwane. Scholars differ in terms of sample selection in case studies as some are of the opinion that a 'typical' case should be presented, whilst others indicate that the extraordinary case should be presented (Barroso 2010). However, the patient with the most severe breast cancer related lymphoedema in terms of volume, was selected for the study.

\section{Data collection methods}

Mixed methods were used to gather data. Self-report data were gathered using a structured interview to explore the patient's general characteristics, her history of health and illness and quality of life, whilst the use of structured observation gathered data on the condition of the patient's affected arm and progress during treatment. During the first consultation, the researcher measured both the patient's arms with a measuring tape and the Four Centimetre Method (Norton School of Lymphatic Therapy 2008), and calculated the volume of each arm using the standard formula for a cylinder. This enabled the researcher to estimate the lymphoedema volume of the affected arm. To monitor progress, the researcher measured the affected arm on a weekly basis or when an increase in volume was suspected. Daily inspections of the patient's skin were conducted 
for signs of dryness, infection, maceration or any other abnormality. Findings were documented on the patient's treatment record which was reviewed periodically. The researcher gathered data from May to August 2009, whilst treating the patient.

Three data gathering instruments were used:

- A questionnaire gathered data on the patient's general characteristics and history of health and illness, with the Numerical Rating Scale of Cancer Pain Intensity. This scale was adapted to determine the patient's quality of life with the lowest number (0) a 'bad life that cannot get worse' and the highest number (10) a 'good life that cannot get better'.

- An Excel spreadsheet served to document the circumference measurements of the patient's arm and to calculate the lymphoedema volume. The treatment record of the patient also served as a data gathering instrument as field notes were made before or immediately after the patient's treatment.

- Photographs were taken as well.

\section{Data analysis}

Content analyses were used to review the treatment record of the patient, and a template, guided by the layout of the case report (McCarthy \& Reilly 2000), was used to categorise the data. Descriptive statistics were used to determine the progress of the patient's arm in terms of volume reduction and the quality of life measured by means of the Numerical Scale.

\section{Case report}

The case report will be presented using the guidelines of McCarthy and Reilly (2000). The induction treatment of the patient's lymphoedematous left arm is presented. A pseudonym is used to ensure her anonymity and confidentiality.

\section{Description of the patient}

Bertha was 61 years old, living in a township in Tshwane, married with three children. Bertha was self-employed and part of the informal business sector.

\section{History of the presenting condition}

Bertha was diagnosed with breast cancer of her left breast in 2002. According to the patient, she was initially misdiagnosed and only diagnosed with breast cancer once the lump in her breast 'was as big as a fist'. She was scheduled to receive six cycles of neoadjuvant chemotherapy but only received four as her finger and toe nails became loose and 'smelled terrible'. After the four cycles of neoadjuvant chemotherapy, a mastectomy, presumably a modified radical mastectomy was performed, followed by radiotherapy. Bertha was unsure of when her left arm started to swell but reported that her arm started swelling significantly 5 years after her breast cancer treatment. She described the swelling as follows:
My arm started swelling little by little ... it started swelling up a little and it would go down, but not everything ... and then it swelled again and go down but not completely ... and so it went on an on ... slowly, slowly ... it was not sore.

Bertha reported the swelling during one of her followup visits to the oncology clinic. She was referred to the occupational therapy department and had a compression garment made for her, but she only wore it 'for a short time ... it did not fit nicely'. In 2009, a member of the public referred Bertha to a private health-care practitioner for the treatment of her lymphoedema but she could not afford private health care and was referred to the researcher after approximately 10 Complete Decongestive Therapy treatments over a period of 1 month.

According to Bertha, she never had cellulites, one of the common lymphoedema related problems, or took any medication for the lymphoedema. She reported suffering from hypertension and visited a primary health clinic every month for the management thereof and attended the oncology clinic annually.

\section{Assessment and care plan}

The general impression of Bertha was one of an overweight person with a huge left arm. Skin inspection revealed a surgical scar on her left anterior chest wall. Radiation fibrosis with telangiectasia was also present; her left arm and hand were enlarged and had various abnormal skin folds; skin changes were present on her hand and forearm (Figure 1) and skin maceration was present between her second and third, third and fourth, and fourth and fifth fingers. No papillomas or lymphoree were detected and no shoulder range of motion impairment was observed. With palpation, no temperature differences between her arms were detected. Pitting could not be induced and fibrotic areas were found on her lymphoedematous forearm. Stemmer's sign was negative. The estimated volume of Bertha's right arm totalled $4615 \mathrm{~mL}$, whilst her left arm totalled $8456 \mathrm{~mL}$; the estimated lymphoedema volume was therefore $3841 \mathrm{~mL}$. Bertha gave her quality of life 10 out of 10 and stated, 'My life is good ... this arm does not prevent me from doing what I want ...'.

Four weeks of induction therapy was planned, comprising manual lymph drainage, 24-hour compression bandages, nail and skincare and patient education 5 days per week with self-bandaging during weekends.

\section{Results \\ Expected outcomes}

The expected outcomes were as follows:

- a $60 \%$ reduction in lymphoedema volume in the planned 4-week induction therapy

- no macerated skin at the end of induction treatment

- a positive influence on the patient's quality of life. 


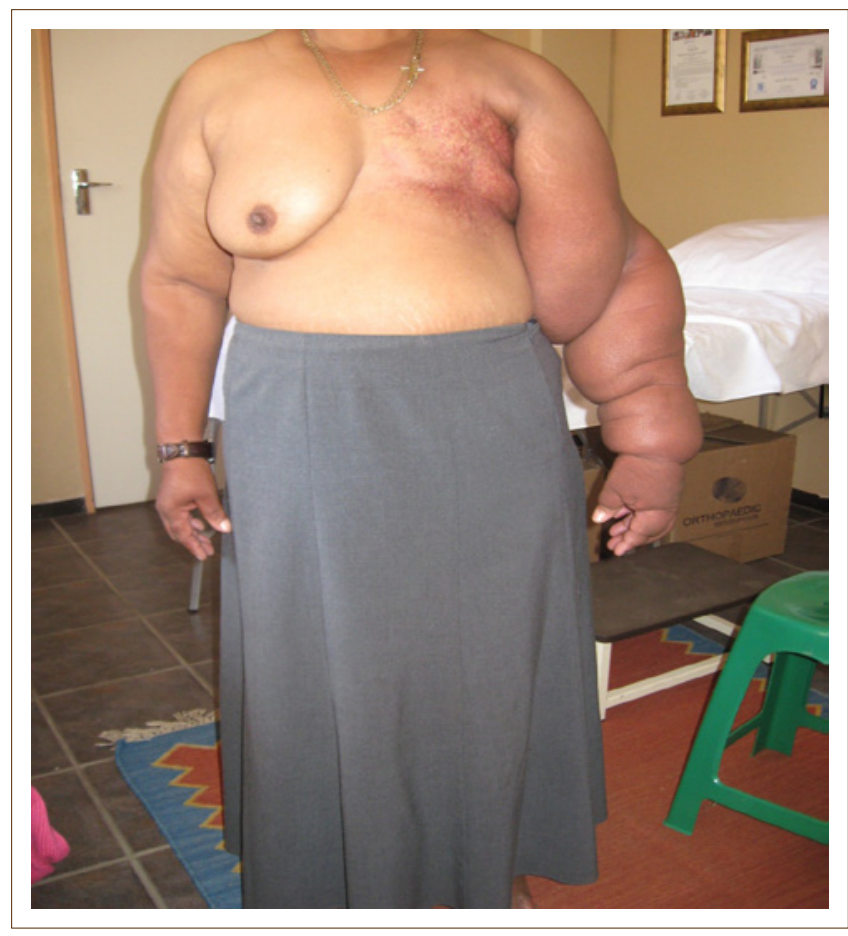

Source: Patient treatment record

FIGURE 1: Bertha's arms at admission.

\section{Outcomes achieved}

The following outcomes were achieved:

- The lymphoedema volume decreased by 33\% decrease after $4 \frac{1}{2}$ weeks of therapy, with a 2-week interruption after the first 12 treatments. A 57.2\% reduction was achieved after an induction period of 10.5 weeks of therapy.

- No skin maceration was present at the end of the induction treatment.

- There was a positive influence on the patient's quality of life. She stated:

This arm still does not prevent me from doing what I want ... it is much lighter ... so light that I can fly (raising her arms above her head) ... I do not wear a towel over my arm any more ... I did that to stop people for looking and asking what happened ...

(Patient)

\section{Ethical considerations}

The ethical principles, as outlined in the Belmont Report (Polit \& Beck 2010), namely beneficence, respect for human dignity and justice, supported the researcher in conducting the study. Firstly, the researcher explained to the participant what lymphoedema was; what Complete Decongestive Therapy consisted of; and the self-care that would be required during the treatment and maintenance phase. After receiving the participant's co-operation, informed consent was obtained. Anonymity and confidentiality were ensured by interviewing and treating the participant in private. The views of the participant were respected and during each treatment session, time was allowed for queries to be raised. The research proposal was peer reviewed by the Departmental and Faculty Research and Innovations Committees of the Tshwane University of Technology and approved by the Ethics Committee of the same university.

\section{Trustworthiness} Validity and reliability

Validity and reliability were ensured by using a recognised method, the Four Centimetre Method, to estimate the volume of the patient's affected arm. Only the researcher took the circumferential measurements of the patient's arms to ensure that the same tension was applied on the measuring tape and that the positions of measurement were consistent. The validity and reliability of the Numerical Rating Scale of Cancer Pain Intensity has been supported by literature (Jensen 2003) and adapted to allow the patient to quantify her quality of life. Trustworthiness was ensured by means of three strategies, namely credibility, dependability and confirmability (Krefting 1991). Shenton (2004) questions whether producing truly transferable results is a realistic aim for a single study as it has the potential to disregard the importance of the context, which is a key factor in qualitative research. Transferability was therefore not a priority. Shenton (2004) guided the researcher with specific requirements to ensure that the strategies were applicable. Credibility was ensured by the researcher's prolonged engagement with the patient which created trust. Sampling was random, as all patients treated by the researcher had an equal probability of being selected. Triangulation was achieved by using different data gathering methods namely, individual interviews, a scale, structured observation, photographs and volumetric measurements. The research proposal for the study was peer reviewed. Member checks were also carried out as the researcher reflected on the self-report data and asked the participant whether the data were documented and understood as intended. Dependability was ensured as a research proposal was written to outline what was planned. The research report serves as evidence of the implementation of the plan, with confirmability ensured by developing an audit trail.

\section{Discussion}

The expected $60 \%$ limb volume reduction could not be achieved. Unfortunately, it was unknown how much the limb volume was reduced during Bertha's treatment at the private health-care practitioner. It might be possible, therefore, that the total reduction was more than $60 \%$ and maybe as high as $68 \%$ which is the highest reduction percentage reported in the literature (Norton School of Lymphatic Therapy 2004). However, a 35\% reduction in lymphoedema volume was achieved after 12 treatments. This compares positively with the findings of Thomas et al. (2007) who found a median lymphoedema reduction of $36 \%$ after 12 treatments. Mondry, Riffenburgh and Johnstone (2004) reported a median reduction of $138 \mathrm{~mL}$ after a median treatment period of 2 weeks (10 treatments). Bertha's volume reduction after 12 treatments was $1095 \mathrm{~mL}$. The median duration of treatment before reaching a measurement plateau is reported to be 2 weeks (Mondry et al. 2004) and 12 treatments (Thomas et al. 2007). Bertha's measurements did not reach a plateau but went up and down. After 6.5 weeks of treatment, a 56.2\% volume reduction was achieved as the lymphoedema 
volume was $1686 \mathrm{~mL}$, but could not be maintained and the lymphoedema volume increased during the next 2 weeks to $1912 \mathrm{~mL}$. It took another 2 weeks of treatment to reduce the limb volume to $1639 \mathrm{~mL}$, a $57.2 \%$ reduction. It was then decided to end the induction treatment phase (Figure 2 illustrates Bertha's left arm at the end of the induction phase) and to start the maintenance phase.

Compliance was a challenge and it affected Bertha's hand. Circumferential measurements were taken on a Friday before treatment; however, the following Monday, when the patient returned for treatment, her hand would be swollen visibly more and painful. It was only after 7.5 weeks of treatment that Bertha confessed that she did not bandage her arm during weekends but wore a compression garment that fits like a worm, going in and out ...' in the skin folds. Bertha further explained that the garment was short and ended above her elbow resulting in her upper arm 'hanging loose'. When inspecting the garment, it was found the garment was a sleeve without a glove or gauntlet. The garment was much too small for Bertha's arm and consequently it formed a tourniquet at her wrist and above her elbow which resulted in the swelling of her hand and forearm, and it was impossible for her upper arm to fit in the compression garment. It also became clear that she may not have had the trained social support to assist her with the bandaging at home that she said she had. Bertha's non-compliance is however not unique, because Mondry et al. (2004) found that an increased number of treatments

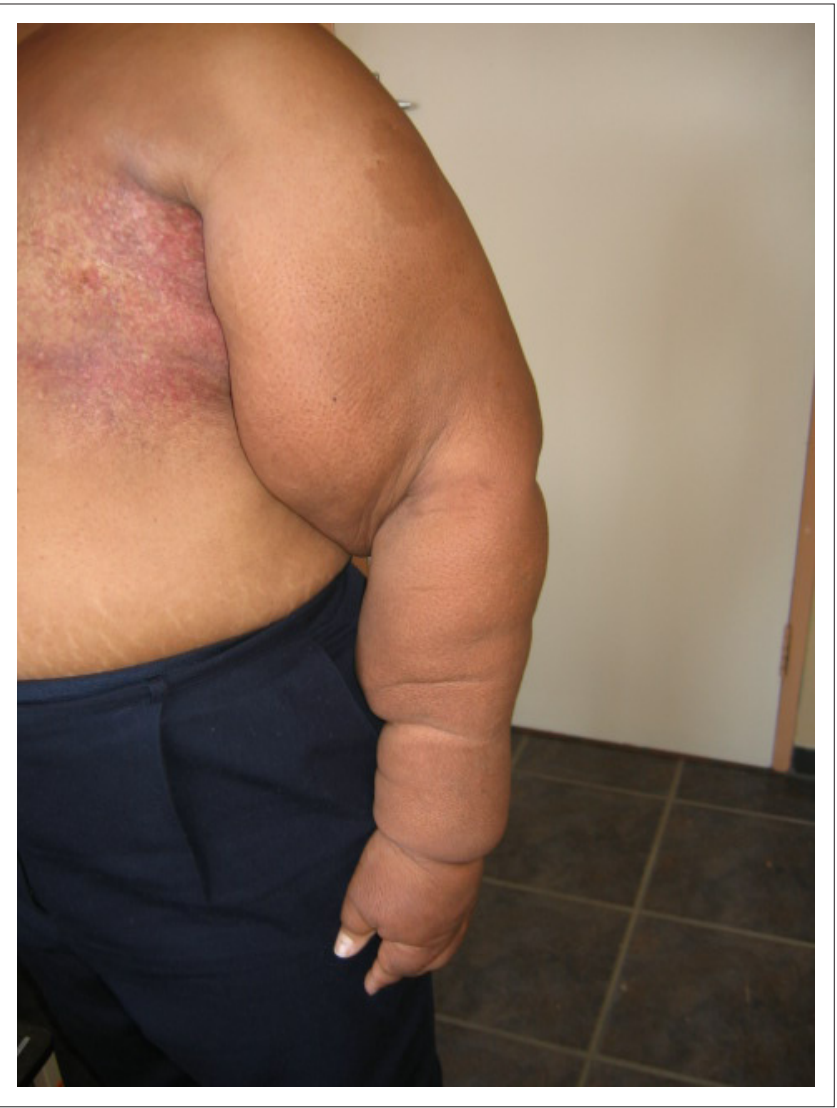

Source: Patient treatment record

FIGURE 2: Bertha's affected arm at the end of induction therapy. resulted in a marked improvement in volume and girth, but poorer compliance. Földi and Földi (2006) are very pragmatic about patient compliance and state that patient compliance to compression therapy in many cases is poor, similar to that of taking prescribed drugs. As experienced with Bertha, noncompliance with decompression therapy automatically leads to relapse.

Despite the fact Bertha rated her quality of life to be 'a good life that cannot get better', the limb volume reduction improved her quality of life. It was unknown if her quality of life would have improved if her lymphoedema did not drastically reduce. Weiss and Spray (2002) found that the quality of life of patients with lymphoedema improves significantly after Complete Decongestive Therapy, irrespective of the limb volume decrease, but Howell and Watson (2005) found the exact opposite. These authors (Howell \& Watson 2005) report that despite a limb volume reduction, the quality of life of most women in their study worsened as they realised that their lymphoedema would require lifelong management and would therefore serve as a reminder of their breast cancer experience.

\section{Limitations of the study}

The study has various limitations. Case studies lead to familiarity with the participant, which limits objectivity, especially if the data were gathered by means of observation with the researcher as the primary or sole observer (Polit \& Beck 2010). Case studies have also been criticised for lacking rigour (Jensen \& Rodgers 2001 in Luck, Usher \& Jackson 2005). Luck et al. (2001), however, advise researchers to address objectivity and rigour issues by planning the case study research and applying the usual requirements for rigour applicable to their chosen methods. Generalisation is also a limitation (Polit \& Beck 2010), as the study reflects the findings applicable to one person in a specific context.

\section{Conclusion}

The study demonstrated and confirmed that despite imperfect patient compliance, breast cancer related lymphoedema can be managed with Complete Decongestive Therapy, with a resultant improvement of the quality of life of women living with breast cancer.

\section{Acknowledgements}

The study was funded by the Tshwane University of Technology.

\section{References}

Barroso, J., 2010, 'Introduction to qualitative research', in G. LoBiondo-Wood \& J. Harber, Nursing research. Methods and critical appraisal for evidence based nursing, 7th edn., pp. 85-99, Mosby, St. Louis.

Berbiglia, V., 2010, 'Orem's Self-care Deficit Theory in nursing practice', in M. Alligood, Nursing Theory. Utilization and application, pp. 261-286, Mosby, Missouri.

Bowling, A., 1996, Measuring disease, Open University Press, Buckingham.

Burns, N. \& Grove, S., 2005, The practice of nursing research: conduct, critique, and utilisation, 5th edn., Elsevier, St. Louis.

Clark, B., Sitzia, J. \& Harlow, W., 2005, 'Incidence and risk of arm oedema following treatment for breast cancer: a three-year follow-up study', QJM: monthly journal of the Association of Physicians 98(5), 343-348. 
Edmond, C., 2003, 'The respiratory system' in M. Alexander, J. Fawcett, \& P. Runciman, (eds.), Nursing practice: hospital and home, pp. 59-86, Churchill Livingstone, Edinburgh.

Fayers, P. \& Machin, D., 2007, Quality of life. The assessment, analyses and interpretation of patient-reported outcomes, Wiley, Sussex.

Földi, E. \& Földi, M., 2006, 'Lymphostatic diseases' in M. Földi \& E. Földi, (eds.), Foldi's textbook of lymphology for physicians and lymphedema therapists. pp. 223-319, Elsevier GmbH, Munich.

Foster, P. \& Bennett, A., 2002. 'Self-care deficit nursing theory. Dorothea E Orem', in: J. George, (ed.) Nursing theories: the base for professional nursing practice, Prentice Hall, New Jersey.

Howell, D. \& Watson, M., 2005, 'Evaluation of a pilot nurse-led, community based treatment programme for lymphoedema', International Journal of Palliative Nursing 11, 62-69. PMid:15798497

Krefting, L., 1991, 'Rigor in qualitative research: the assessment of trustworthiness', American Journal of Occupational Therapy 45, 214-222. PMid:2031523

Lawenda, B.D., Mondry, T.E. \& Johnstone, P.A.S., 2009, 'Lymphedema: A primer on the identification and management of a chronic condition in oncologic treatment', $C A$ A Cancer Journal for Clinicians 59, 8-24. doi:10.3322/caac.20001, PMid:19147865

Luck, L., Jackson, D. \& Usher, K., 2001, 'Case study: a bridge across paradigms', Nursing Inquiry 13, 103-109. doi:10.1111/j.1440-1800.2006.00309.x, PMid:16700753

Mondry, T.E., Riffenburgh, R.H. \& Johnstone, P.A.S., 2004, 'Prospective Trial of Complete Decongestive Therapy for Upper Extremity Lymphedema After Breast Cancer Therapy', The Cancer Journal 10, 42-48. doi:10.1097/00130404Breast Cancer Therapy', The Cancer
200401000-00009, PMid:15000494

McCarthy, L.H. \& Reilly, K.E., 2000, 'How to write a case report', Family Medicine 32(3), 190-195. PMid:10726220
Norton School of Lymphatic Therapy, 2008, Course manual. Manual lymph drainage/ complete decongestive therapy. Certification training, Norton School of Lymphatic Therapy, Matawan.

Orem, D., 1995, 'Nursing: Concepts of Practice', 3rd edn., McGraw-Hill, New York.

Petreck, J. \& Heelan, M., 1998, 'Incidence of breast carcinoma-related lymphedema', Cancer 15(83), 2776-2781. doi:10.1002/(SICI)10970142(19981215)83:12B+<2776::AID-CNCR25>3.0.CO;2-V

Polit, F.D. \& Beck, C.T., 2004, Nursing research; principles and methods, 4th edn., Lippincott, Philadelphia.

Shenton, A., 2004, 'Strategies for ensuring trustworthiness in qualitative research projects', Education for Information 22, 63-75.

SouthAfrica.info, 2010, Geography and climate, viewed 16 August 2010, from http:// www.southafrica.info/about/geography/gauteng.htm

Thomas, R.C., Hawkins, K., Kirkpatrick, S.H., Mondry, T.E., Gabram-Mendola, S. \& Johnstone, P.A., 2007, 'Reduction of lymphedema using complete decongestive therapy; roles of prior radiation therapy and extent of axillary dissection', Journal of the Society of Integrative Oncology 5(3), 87-91. PMid:17761127

Weiss, J. \& Spray, B., 2002, 'The effect of complete decongestive therapy on the quality of life of patients with peripheral lymphedema', Lymphology $35,46-58$. PMid:12081052

Weissleder, H. \& Schuchhardt, C., 2008, 'Primary lymphedema' in H. Weissleder \& C. Schuchhardt (eds.), Lymphedema. Diagnosis and therapy, Essen, Viavital Verlag $\mathrm{GmbH}$.

Zuther, J., 2005, Lymphedema management. The comprehensive guide for practitioners, Thieme, New York. 